\title{
A FUNÇÃO SOCIAL, CULTURAL E ARTÍSTICA DA IMAGEM FOTOGRÁFICA
}

Patricia Peruzzo Lopes ${ }^{1}$

\section{Resumo}

O objetivo deste trabalho é analisar as mudanças que ocorreram nas práticas do olhar de uma sociedade acostumada a visualizar imagens a partir de representações pictóricas e das diferentes técnicas da gravura. É, também, tentar compreender como, após o advento da fotografia, no segundo quarto do século XIX, modificaram-se os regimes de visualidade presentes nesta sociedade. É notório que com a disseminação da fotografia, enquanto técnica, alterou-se a relação das pessoas com as imagens, não somente sob prismas artísticos e estéticos, mas sob aspectos sociais, culturais e políticos. Traço um panorama da trajetória da fotografia e explicito sua relação com a arte e com a educação. Para isso, dialogo com as teorias propostas por Boris Kossoy e Rosalind Krauss, que procuram traçar um panorama histórico-cultural da Fotografia, e também, com François Soulages no que tange a pesquisa estética na/da Fotografia. Aproprio-me das proposições de Cerqueira e de Barros para pensar na relação entre fotografia e educação.

Palavras-chave: Fotografia; História; Reproduções Fotográficas; Arte; Museu

\footnotetext{
1 Arte-educadora na Fundação Catarinense de Cultura (FCC)/Secretaria de Estado do Turismo, Cultura e Esporte. Doutoranda no Programa de Pós-Graduação em Educação (PPGE) da Universidade Federal de Santa Catarina (UFSC) na linha de pesquisa Educação e Comunicação. Endereço: Servidão Rio Vermelho, 72 - casa, Bairro: São João do Rio Vermelho - Florianópolis, Santa Catarina. E-mail: paperuzzo@ gmail.com
} 


\section{O PRINCÍPIO DA FOTOGRAFIA}

Proponho, com este artigo, analisar algumas mudanças no campo da Arte, especialmente no que se refere à forma como analisamos as imagens após o advento da Fotografia. Uma técnica que também propiciou mudanças significativas no panorama social e cultural do século XIX.

Com o advento da Revolução Industrial, na segunda metade do século XIX, constatase um enorme desenvolvimento das ciências: surge, naquele processo de transformação política, econômica e sociocultural, uma série de inventos que viriam entusiasmar a sociedade oitocentista e alterar decisivamente os rumos do que conhecemos por história moderna. Um destes inventos, a fotografia, teria papel fundamental neste contexto, enquanto possibilidade de informação e conhecimento e, também, instrumento de apoio à pesquisa nos diferentes campos da ciência, incluindo o campo da arte, ou seja, para os desenhistas e pintores desta época, que a utilizavam como ferramenta de apoio para observação das vistas e paisagens. $\mathrm{O}$ próprio termo 'vista' (Fig. 1), de acordo com Krauss (2002, p. 47), "era utilizado pela prática estereoscópica $^{2}$ para designar seu objeto e permitia localizar a especificidade deste tipo de imagem". Conforme Krauss,

De início, a palavra 'vista' evocava a espetacular profundidade que acabo de descrever, organizada segundo as leis da perspectiva. Este fenômeno foi freqüentemente reforçado ou simplesmente levado em conta por aqueles que faziam vistas estereoscópicas, na sua maneira de estruturar as imagens em torno de um ponto de referência vertical no primeiro ou segundo plano - o que tinha por efeito centrar o espaço representando, dentro do próprio campo visual, a convergência dos olhos em direção ao ponto de fuga. (KRAUSS, 2002, p. 47).

\footnotetext{
2 "O tipo de percepção proporcionado pelo estereoscópio cria uma situação comparável à do cinema. As duas implicam no isolamento do espectador com uma imagem apartada de qualquer intrusão do mundo exterior. Nos dois casos, a imagem transporta o espectador pelos olhos, enquanto seu corpo permanece imóvel. Em ambos os casos, o prazer provém da experiência do simulacro, esta aparência de realidade cujo efeito de real não pode ser verificado por qualquer deslocamento físico real na cena". (KRAUSS, 2002, p. 46)
} 


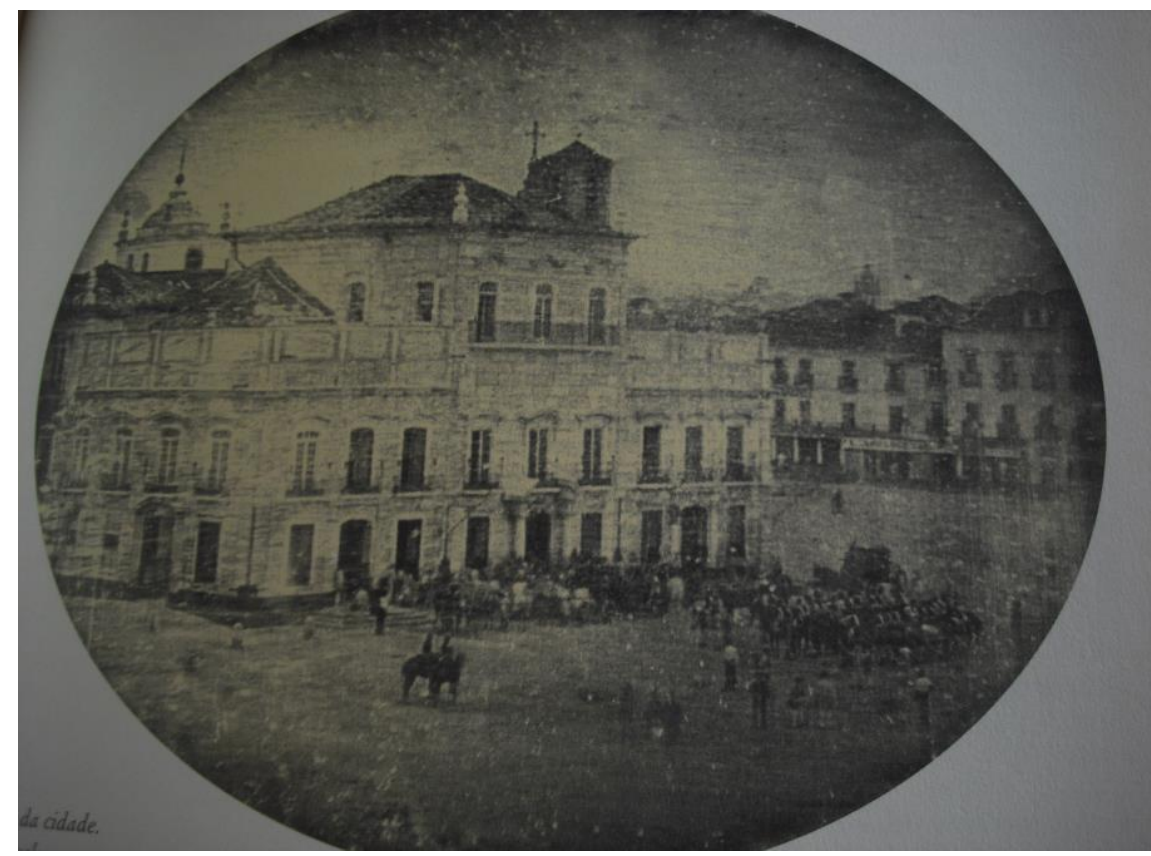

Figura 1. Paço da cidade. Possivelmente a primeira vista pelo sistema de daguerreótipo tomada na América do Sul. Rio de Janeiro, 17 jan. 1840, 7x9 cm. Reprodução fotográfica. Coleção DPOB.

Paralelamente a isto, a fotografia também era analisada como forma de expressão artística, pois, no início, antes de existirem as técnicas fotográficas, os retratos das pessoas eram feitos por pintores e estes, gradativamente, foram sendo substituídos pelas carte-de$v_{\text {visite }}^{3}$ (Fig. 2), também conhecidas como cartões de visita com fotografias das pessoas em um tamanho miniatura e com o respectivo nome do retratado. Este formato foi inicialmente lançado pelo francês André Adolphe Eugène Disdéri por volta do ano 1859.

\footnotetext{
3 "Carte-de-Visite: a carte de visite - a mais importante das aplicações do colódio - nada mais era que uma fotografia copiada em papel (em geral albuminado) e colada sobre um cartão-suporte, no formato de um cartão de visitas [...] foi basicamente utilizada para o retrato, e ganhou enorme difusão em todo o mundo. Seu baixo custo de produção popularizou o retrato fotográfico, tornando-o acessível a uma ampla clientela. Por outro lado, a ideia de oferecer o retrato com dedicatória contribui ainda mais para o consumo generalizado, tornando-se a carte-de-visite o modismo maior que a fotografia conheceu durante o século XIX”. (KOSSOY, 1989, p. 104)
} 


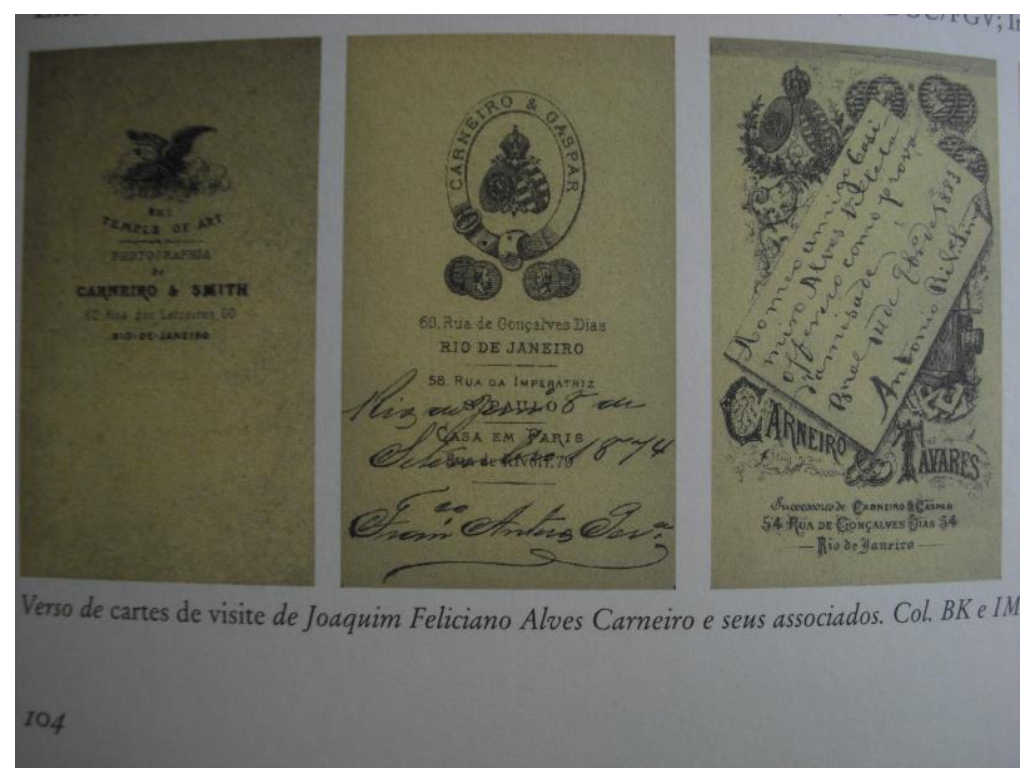

Figura 2. Diferentes modelos de carte-de-visite de Joaquim Feliciano Alves Carneiro e seus associados. Reprodução fotográfica. Coleção BK e IMS.

Além da carte-de-visite (imagem de 9,5 x $6 \mathrm{~cm}$ sobre cartão de 10,5 x 6,5 cm), havia outros formatos, menos populares e em tamanhos maiores, como a cabinet-portrait e cartecabinet (imagem de 14 x 9,5 cm aproximadamente sobre cartão de $16,5 \times 11 \mathrm{~cm}$ ) ou ainda maior como o formato promenade (cartão de 18 x 10,3 cm) e o formato boudoir (cartão de 21,8 x 14,3 cm). De acordo com Kossoy,

\begin{abstract}
Com os novos recursos técnicos introduzidos pela indústria fotográfica européia e norte-americana na década de 1850 e com o decorrente surgimento da carte-devisite, os custos de produção para o fotógrafo baixaram e os preços para o cliente também se tornaram acessíveis. Concomitantemente, o modismo de se retratar e oferecer retratos se expandiu por todo o mundo. Democratizava o retrato do homem através da fotografia [...]. O retrato fotográfico tornava-se uma necessidade do ponto de vista psicológico, pois o homem em todas as latitudes nele percebera uma possibilidade de perpetuação de sua própria imagem. Por que não 'congelar' sua imagem de forma nobre? (KOSSOY, 2009, p.114-115).
\end{abstract}

\title{
2 FOTOGRAFIA E ARTE, RELAÇÕES POSSÍVEIS...
}

Antes do surgimento da fotografia, na primeira metade do século XIX, apenas era possível observar o retrato de uma pessoa através das técnicas de pintura a óleo, têmperas, afrescos ou de gravuras, como as gravuras feitas em chapas de metal com a técnica da águaforte e as gravuras feitas sobre blocos de pedra, como as litografias. Estes retratos também não eram acessíveis a grande parte da população, somente pessoas ligadas à igreja e à 
LOPES, Patricia Peruzzo.

nobreza, e, posteriormente, à burguesia tinham condições de ter sua imagem perpetuada sobre telas ou papel, feitos por artistas e por seus aprendizes. Com o advento da fotografia, a categoria dos retratos modificou-se consideravelmente, pois se tornou acessível a uma grande parcela da população já no final do século XIX. Benjamin afirma que,

Em sua essência, a obra de arte sempre foi reprodutível. O que os homens faziam sempre podia ser imitado por outros homens. Essa imitação era praticada por discípulos, em seus exercícios, pelos mestres, para a difusão das obras, e, finalmente por terceiros, meramente interessados no lucro. Em contraste, a reprodução técnica da obra de arte representa um processo novo, que se vem desenvolvendo na história intermitentemente, através de saltos separados por longos intervalos, mas com intensidade crescente. (BENJAMIN, 1994, p. 166, grifo meu).

Lichtwark (LICHTWARK, 1907 apud BENJAMIN, 1994, p. 103) já anunciava que "nenhuma obra de arte é tão contemplada tão atentamente em nosso tempo como a imagem fotográfica de nós mesmos, de nossos parentes próximos, de nossos seres amados" (Fig. 3 e Fig. 4). Neste caso, Benjamin promove a retirada da investigação da esfera das distinções estéticas e transpõe-na para as funções sociais. Para este autor, ao tentar compreender os usos e funções da fotografia no início do século XX, devemos pensar sobre o quão é característico que o debate tenha se concentrado na estética da 'fotografia como arte', ao passo que poucos se interessavam, por exemplo, pelo fato bem mais evidente da 'arte como fotografia'.

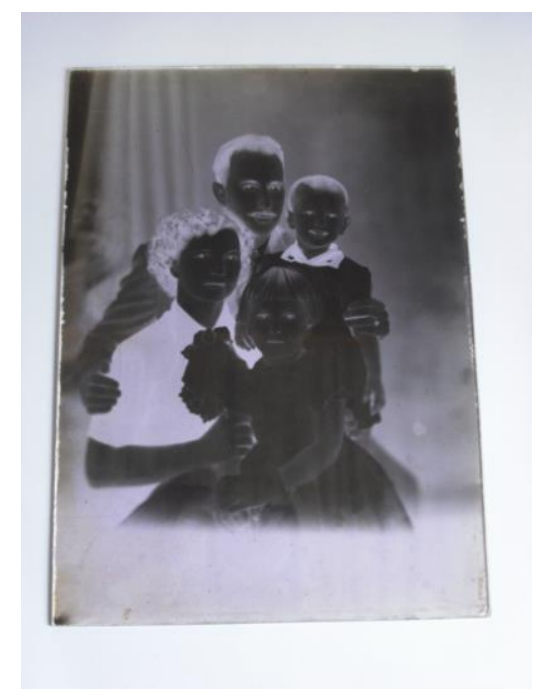

Figura 3. Retrato fotográfico em estúdio, Arthur A. Peruzzo, Elidia Vicari Peruzzo e seus filhos, cerca de 1952.

Negativo Fotográfico em Chapa de Vidro. Coleção Particular. 
A distinção entre a arte dos fotógrafos e a fotografia dos artistas não é de fácil compreensão, pois se baseia na 'fratura cultural', social e estética que separa os artistas dos fotógrafos-artistas e pode ser um tanto imprecisa. Para Rouillé (2009, p. 235), “ao contrário do artista, que se situa no mesmo nível no campo da arte, o fotógrafo-artista evolui deliberadamente no campo da fotografia. Ele é fotógrafo, antes de ser artista”. Segundo Rouillé (2009, p. 235-236), “de fato, bom número de fotógrafos-artistas exerce sua arte à margem de sua atividade documental, a fotografia preenchendo, ao mesmo tempo, o lugar de sua profissão e de sua arte". De acordo com Benjamin,

Se alguma coisa caracteriza a relação moderna entre arte e fotografia, é a tensão ainda não resolvida que surgiu entre ambas quando as obras de arte começaram a ser fotografadas. Muitos fotógrafos que determinam os contornos atuais dessa técnica partiram da pintura. Eles a abandonaram na tentativa de colocar seus meios de expressão numa relação viva e inequívoca com a vida contemporânea [...] (BENJAMIN, 1994, p. 104).

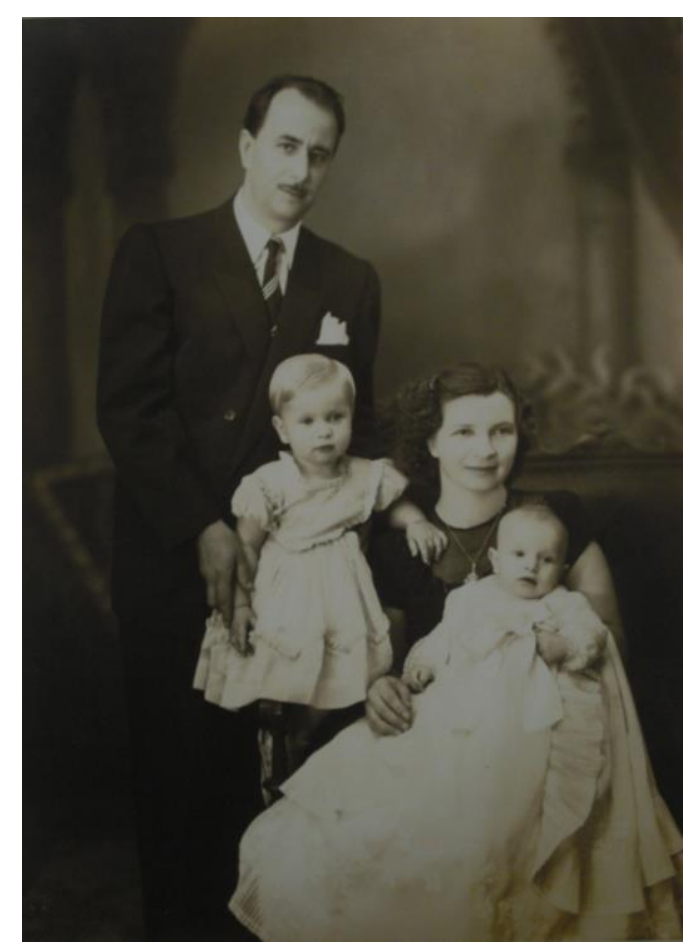

Figura 4. Retrato fotográfico em estúdio, Arthur A. Peruzzo, Elidia Vicari Peruzzo e seus filhos, cerca de 1950. Fotografia em Papel. Coleção Particular.

Esta tensão, existente entre as duas técnicas, sempre foi passível de reflexões, de acordo com cada época, ou toda vez que se ousou compará-las e aproximá-las. Por outro lado, há quem considere tais comparações irrelevantes. Então, qual o seu sentido? Para que servem? 
LOPES, Patricia Peruzzo.

A quem convém? Seria para o mercado da arte? Ou então, seria para os colecionadores e para os restauradores?

Ao acompanhar o pensamento de Benjamin (1994, p. 104), "cada um de nós pode observar que uma imagem, uma escultura e principalmente um edifício são mais facilmente visíveis na fotografia que na realidade", pois, em relação ao original, "a reprodução técnica tem mais autonomia que a reprodução manual". Ela pode, por exemplo, pela fotografia, "acentuar certos aspectos do original, acessíveis à objetiva - ajustável e capaz de selecionar arbitrariamente o seu ângulo de observação - mas não acessível ao olhar humano [...]”. De acordo com este autor,

Os fotógrafos que passaram das artes plásticas à fotografia, não por razões oportunísticas, não acidentalmente, não por comodismo, constituem hoje a vanguarda dos especialistas contemporâneos, porque de algum modo estão imunizados por esse itinerário contra o maior perigo da fotografia contemporânea, a comercialização. (BENJAMIN, 1994, p. 105).

Necessário se faz lembrar que, embora o título da publicação de Benjamin seja de 1994, a primeira edição em português é do ano de 1985, e este ensaio foi escrito por este autor originalmente no ano de 1931. Assim, sua expressão "vanguarda dos especialistas contemporâneos" deve ser entendida com o devido distanciamento temporal.

De qualquer modo, Benjamin aponta para uma questão importante, qual seja, o mercado, principalmente em função da socialização da imagem fotográfica, dado seu custo. Esta comercialização teria íntima relação com a serialização e a reprodução mecânica das imagens e, consequentemente, sua banalização ou perda de status artístico. É como se fossemos tentados a substituir o objeto real pela sua reprodução fotográfica, e aceitássemos passivamente esta substituição, sem ao menos fazer uma reflexão acerca deste processo.

Para Soulages (2010, p. 296), de fato, "a pintura teve que ser repensada de outro modo em sua relação com a questão da imitação dos fenômenos visuais e, às vezes, se metamorfosear". Ainda de acordo com este autor, "a fotografia foi, pois, uma instância que levou a pintura a se transformar, com o risco de se aniquilar", referindo-se não a qualquer pintura, mas a certo tipo de pintura, como, por exemplo, os retratos em tamanho natural ou convencional. Picasso questionava-se a respeito deste tipo de pintura e indagava: 
Por que o artista insistiria em realizar o que pode ser tão bem fixado com a ajuda da objetiva? Isso seria uma loucura, não é verdade? A foto chegou no momento certo para libertar a pintura de qualquer história banal, de qualquer literatura e até do tema. Não deveriam os pintores aproveitar sua liberdade reconquistada para fazer algo diferente? ${ }^{4}$ (PICASSO, 1969, p. 80, apud SOULAGES, 2010, p. 297).

As questões formuladas por Pablo Picasso contêm, talvez, a mais importante justificativa para o surgimento dos diversos movimentos da arte moderna: a despreocupação com o 'referente' e as possibilidades de explorar a plasticidade dos materiais, a originalidade da expressão individual, entre outros aspectos que só foram possíveis graças ao fato de a fotografia assumir a condição de reprodução 'fiel' da realidade.

Conforme Soulages (2010, p. 297), “a fotografia, em vez de ser a camera obscura por excelência, liberta a pintura desta última e de todas as condições epistêmicas e estéticas que a tornam possível", em vez de "ser normativa, ela é condição de liberdade para a pintura". Esta liberdade conclui-se através do registro fotográfico diante das obras de arte e da reprodução destes registros. Ainda de acordo com Soulages,

Conhecem-se as obras de arte não mais pelo texto que as descreve, nem pelo desenho ou pela gravura, mas através da fotografia, o que leva Malraux a escrever, um século depois do anúncio feito por Arago que "há cem anos, a história da arte, desde que escapou ao controle dos especialistas, é a história do que é fotografável", Esse meio não é, portanto, tão neutro, à medida que a relação direta com a obra é substituída por sua relação fotográfica - e a recepção pode ser a mesma. (SOULAGES, 2010, p. 318).

De fato, com o advento da fotografia, o mundo passou a ser conhecido através de diversos formatos, pois as câmeras fotográficas (Fig. 5) padronizavam as imagens em tamanhos como, por exemplo, $5 \times 7$ polegadas, 8x10 polegadas ou, ainda, $6 \times 6 \mathrm{~cm}$. Além disso, não mais seria preciso estar diante de uma obra de arte em um museu ou diante de um monumento, bastaria tirar fotografias e mostrá-las ao público receptor que estes decodificariam ou, ao menos, conheceriam tais imagens.

\footnotetext{
${ }^{4}$ Esta citação é parte de uma conversa de Pablo Picasso com Brassaï, publicada com o título: Conversation avec Picasso. Paris: Gallimard, 1969, p.80 - (Coleção Idées).

${ }^{5}$ Expressão utilizada por Malraux em Les voix du silence. Paris: Gallimard, 1952, p. 28. - (Coleção La Galerie de La Pléiade).
} 
LOPES, Patricia Peruzzo.

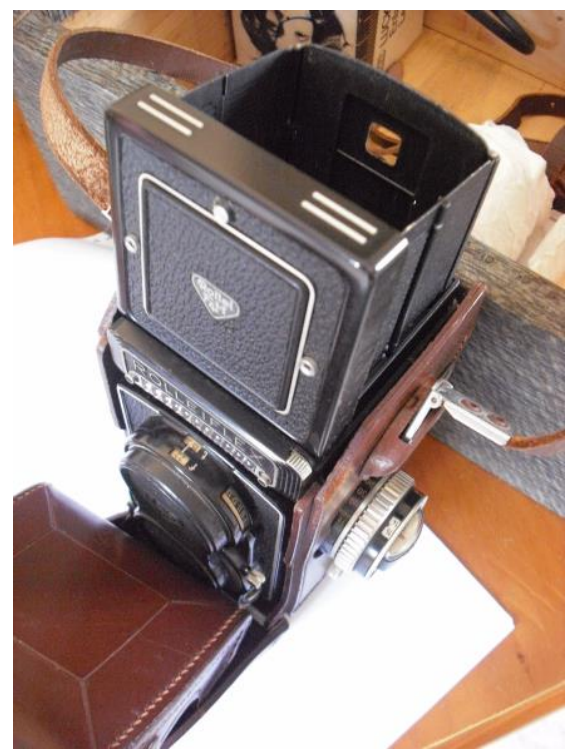

Figura 5. Câmera Rolleiflex, de médio formato, $6 \times 6$ cm. 2012. Fotografia. Coleção Particular.

A partir da fotografia, o mundo, segundo Kossoy (2009, p. 27), “tornou-se, assim, portátil e ilustrado". A fotografia - enquanto técnica e expressão - colaborou para que se difundissem e tornassem acessíveis as diferentes categorias de patrimônio cultural, como, por exemplo, os monumentos, os bustos e as esculturas inseridas no espaço público. Para Nedel, a noção de patrimônio passou por significativas mudanças no período pós-segunda guerra mundial, "Do singular "histórico-cultural" ao adjetivo plural, o patrimônio desdobrou-se em urbano, industrial, genético, natural, paisagístico, ambiental, arqueológico, percorrendo uma declinação semântica que não mais se atém aos limites do mundo material” (NEDEL, 2011, p. 07).

Muito do que conhecemos, como exemplos desta categoria de patrimônio, chegou para nós através de reproduções das imagens fotográficas. A questão da reprodução aparece presente num ensaio realizado por Walter Benjamin, em 1936, quando refletiu acerca da obra de arte na era de sua reprodutibilidade técnica. Trata-se de um ensaio clássico sobre o tema no qual o autor mostrou que a reprodução de um objeto é algo bem mais comum do que supomos, tornando as imagens, ora reproduzidas através da fotografia, acessíveis a um número maior de pessoas. Porém, concluiu que sempre haverá uma perda significativa e uma 
transformação nas modalidades de recepção, pois nesta modalidade estará ausente o hic et $n u n c^{6}$ da obra de arte, sua existência única no lugar em que ela se encontra. Para Benjamin,

\begin{abstract}
O aqui e agora do original constitui o conteúdo da sua autenticidade, e nela se enraíza uma tradição que identifica esse objeto, até nossos dias, como sendo aquele objeto, sempre igual e idêntico a si mesmo. A esfera da autenticidade, como um todo, escapa à reprodutibilidade técnica, e naturalmente não apenas à técnica. Mas, enquanto o autêntico preserva toda a sua autoridade com relação à reprodução manual, em geral considerada uma falsificação, o mesmo não ocorre no que diz respeito à reprodução técnica [...] (BENJAMIN, 1994, p.167-168).
\end{abstract}

Podemos afirmar que, embora sejam passíveis de reprodução, os negativos fotográficos impressos sobre as chapas vidro do final do século XIX (Fig. 6), conservam esta aura, pois muitos desses negativos são guardados, até hoje, como verdadeiras jóias ou obras de arte; assim como também as placas de prata, iodadas e expostas na camera obscura feitas por Daguerre em suas primeiras experiências com os daguerreótipos. De acordo com Benjamin (1994, p. 168), essas placas “eram peças únicas e por volta do ano de 1839, eram comercializadas por 25 francos-ouro", na França. Qual o valor de tais peças nos dias de hoje? E a qual categoria do campo da arte pertencem?

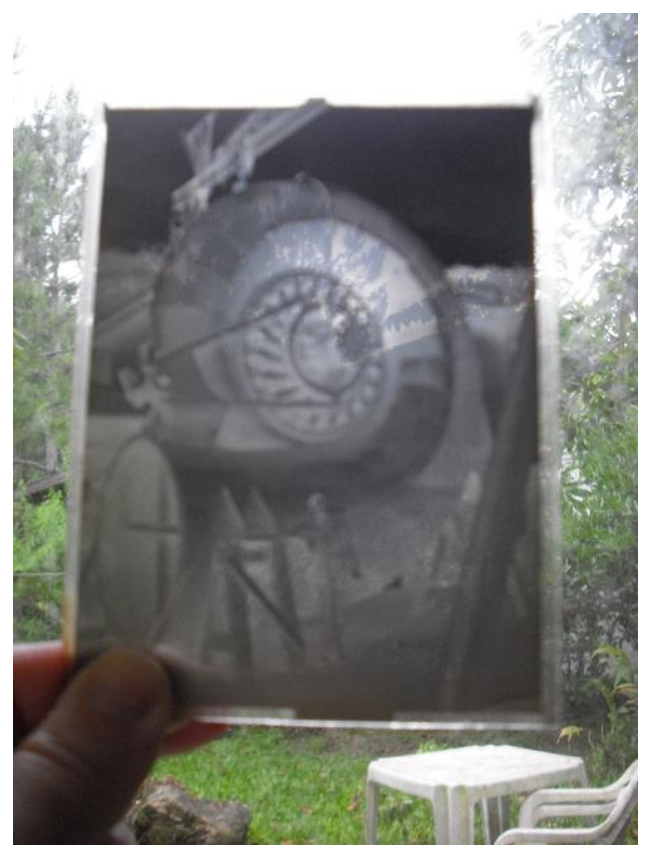

Figura 6. Peça de usina em Herval d' Oeste, SC. 2012. Negativo Fotográfico em Chapa de Vidro.

Coleção Particular.

\footnotetext{
${ }^{6}$ Expressão em Latim que significa 'aqui e agora'.
} 
LOPES, Patricia Peruzzo.

Tomando por base o pensamento desenvolvido por Annateresa Fabris (2009, p. 21), podemos conjeturar que "a fotografia não é um fato natural, como o século XIX poderia fazer supor, mas um objeto cultural que responde a um projeto preciso e cujo significado não pode dispensar a análise do momento em que surgiu”. Este objeto cultural, denominado fotografia, entretanto, em pleno século XXI, de acordo com Kossoy $(2009$, p. 28), "ainda não alcançou plenamente o status de documento, que, no sentido tradicional do termo sempre significou o documento escrito, manuscrito, impresso na sua enorme variedade". Isto porque as fotografias ainda são vistas pela sociedade como uma espécie de suplemento ilustrado dos textos verbais que circulam diariamente e que estamos acostumados a ler e acessar. Para Kossoy,

\begin{abstract}
Sua importância enquanto artefato de época, repletos de informações de arte e técnica, ainda não foi devidamente percebida: as múltiplas informações de seus conteúdos enquanto meios de conhecimento têm sido timidamente empregados no trabalho histórico. Por outro lado, investigações de cunho científico acerca da história da fotografia - inserida num contexto mais amplo da história da cultura - são ainda raras. (KOSSOY, 2009, p. 28).
\end{abstract}

As instituições, como os museus, as casas de memória e os arquivos públicos municipais e estaduais, que guardam este tipo de documentação fotográfica, devem compreender que, à medida que esta se distancia da época em que foram produzidos ou tomados tais registros, mais difíceis são as possibilidades de suas informações visuais e técnicas serem resgatadas, e, portanto, menos favorável serão ao conhecimento, justamente por não terem sido estudadas convenientemente desde o momento que passaram a integrar as coleções destas instituições. Considerando somente as imagens e registros fotográficos que, realmente, foram salvaguardadas nas instituições mencionadas anteriormente, Kossoy (2009, p. 30) pondera: "creio que não haveria exagero em dizer que sempre existiu certo preconceito quanto à utilização da fotografia como fonte histórica ou instrumento de pesquisa". Para este autor, há duas causas para que isto aconteça,

A primeira é de ordem cultural: apesar de sermos personagens de uma "civilização da imagem" - e neste sentido alvos voluntários e involuntários do bombardeio contínuo de informações visuais de diferentes categorias emitidas pelos meios de comunicação -, existe um aprisionamento multissecular à tradição escrita como forma de transmissão do saber, como bem esclarecia Pierre Francastel décadas atrás; nossa herança livresca predomina como meio de conhecimento científico. A 
fotografia é, em função dessa tradição institucionalizada, geralmente vista com restrições. (KOSSOY, 2009, p. 30).

Podemos citar, por exemplo, como caso para ilustrar esta primeira questão: qual é o autêntico valor dado à fotografia em nossa sociedade, pois mesmo para aqueles que se dedicam a compreender e a pesquisar sobre fotografia, em termos locais, regionais ou nacionais, existe uma carência de pesquisas e publicações sobre esse assunto. A segunda razão decorre da anterior e

Diz respeito à expressão. A informação registrada visualmente configura-se num sério obstáculo tanto para o pesquisador que trabalha no museu ou arquivo como ao pesquisador usuário que freqüenta estas instituições. O problema reside justamente em aceitar, analisar e interpretar a informação quando esta não é transmitida segundo um sistema codificado de signos em conformidade com os cânones tradicionais da comunicação escrita. (KOSSOY, 2009, p. 30).

\section{FOTOGRAFIA E EDUCAÇÃO, APROXIMANDO CAMPOS...}

Estamos acostumados a visualizar as imagens, mas não a decodificá-las e a percebêlas dentro de um contexto mais amplo. Pois, para que isto aconteça, efetivamente, é necessário tempo. Tempo para olhar, tempo para 'passear' sobre as imagens, tempo para compreendê-las em sua totalidade e em sua unicidade, tempo para refletir e para estruturá-las num devido espaço e tempo. Vivemos em uma sociedade culturalmente imagética, porém, nem todos nós dispomos de capacidade crítica para analisá-la e interpretá-la adequada e coerentemente. Ao contrário, quanto mais se produzem imagens, mais aceleramos nossos processos de percepção visual, se é que assim podemos chamar, hoje, o ato de ver na contemporaneidade. De acordo com Hernández,

\footnotetext{
A cultura visual não seria um tanto um quê ou um como, pois se constitui como um espaço de relação que traça pontes no 'vazio', que se projeta entre o que vemos e como somos vistos por aquilo que vemos. A cultura visual, quando se refere à educação, pode se articular como um cruzamento de relatos em rizoma que permite indagar sobre as maneiras culturais de olhar e seus efeitos sobre cada um de nós. Por isso, não nos enganamos e pensamos (sabemos) que não vemos o que queremos ver, mas sim aquilo que nos fazem ver [...]. (HERNÁNDEZ, 2011, p. 34).
}

Neste sentido, as publicações de livros de arte, de fotografia e dos livros com seus suplementos didáticos elaborados para escolas teriam um papel fundamental como facilitadores e difusores das imagens. Os livros seriam como veículos incentivadores na 
LOPES, Patricia Peruzzo.

promoção da leitura e apropriação de tais imagens. Na contemporaneidade, percebemos uma intensa produção de imagens - inclusive produzidas pelos próprios alunos - porém, há um pequeno espaço destinado à reflexão acerca deste tema na escola, no caso, o estudo da imagem.

Com isso, os jovens optam por se apropriar das imagens através das redes sociais e de outras mídias, em detrimento da escola e dos materiais utilizados por professores em suas aulas. O interesse por reproduções de imagens impressas em papel diminui na medida em que crescem o estímulo e o acesso às imagens disponibilizadas através de novas tecnologias e categorias midiáticas.

Assim como as edições dos livros de Arte e de Fotografia, os museus também teriam esta função: difundir acervos de imagens de ou sobre determinada cultura ou categoria estética, por meio da organização das exposições e do preparo dos catálogos e materiais didáticos distribuídos durante o período de determinada exposição. De acordo com Krauss (2002, p. 48), “a história da arte moderna é produto do espaço de exposição mais rigorosamente estruturado do século XIX, ou seja, o museu”. Para esta autora,

Foi André Malraux que formulou a teoria sobre o modo como o museu, por sua vez, organiza coletivamente a representação dominante da Arte através da sucessão de estilos e representações que oferece. Os museus se modernizaram com a instituição do livro de arte e os museus de Malraux se tornaram hoje em dia 'museus imaginários, sem paredes', encontrando-se o conteúdo de suas galerias amontoado em um vasto conjunto coletivo pela reprodução fotográfica. (KRAUSS, 2002, p. 48-49, grifo meu).

Esta questão, da reprodução fotográfica da arte, revela que podemos reformular a maneira como lidamos atualmente com as imagens, pois, não é mais necessário estar em determinado local ou museu para se ter acesso ao objeto físico que se encontra neste lugar, nos contentamos em contemplar e analisar o resultado da imagem obtida através de um equipamento mecânico de captação e reprodução. Para Kossoy (2009, p. 36), “toda fotografia tem sua origem a partir do desejo de um indivíduo que se viu motivado a congelar em imagem um aspecto dado do real, em determinado lugar e época”. Conforme este mesmo autor (2009, p. 36-37), “a imagem do real retida pela fotografia (quando preservada ou reproduzida) fornece o testemunho visual e material dos fatos aos espectadores ausentes da cena". 
$\mathrm{Na}$ atualidade, o uso das novas tecnologias e dispositivos virtuais, como os aplicativos desenvolvidos para os computadores pessoais e para os telefones móveis, facilitaram a propagação das imagens fotográficas. O modo de se comunicar utilizando imagens capturadas pelas câmeras destes aparelhos e divulgadas através de meios eletrônicos tornou-se algo corrente na contemporaneidade desses espectadores, que realmente não precisariam estar presentes na cena.

A escola, que deveria ser, por natureza e por atribuição legal, a principal mediadora do conhecimento, mal havia conseguido 'deglutir' e 'digerir' as repercussões sociais, econômicas, políticas, históricas, éticas e estéticas ocasionadas pelo advento da fotografia, quando - há cerca de vinte anos - ocorreu o início de uma verdadeira revolução tecnológica, a qual se caracteriza pela preferência pela linguagem visual, com o uso das fotografias digitais aos ícones adotados em todos os softwares usados nos computadores e dispositivos móveis de comunicação, fazendo com que as questões referentes ao uso das imagens fotográficas tivessem que ser repensadas, quanto aos seus usos e as suas aplicações.

De acordo com Fábio V. Cerqueira,

Nos dias de hoje, o adolescente fotografa, ludicamente, qualquer bobagem, usufruindo tecnologia digital, seja com uma câmera fotográfica ou com um aparelho celular, transferindo estas imagens para seu microcomputador, divertindo-se então com esta panacéia imagética, ao jogar este manancial de informações visuais no universo virtual da Internet. (CERQUEIRA, 2008, p. 189).

Diante disto, é bem possível que possamos afirmar que esses mesmos adolescentes sequer compreendam a real dimensão da fotografia dentro de um contexto cultural mais amplo. Cerqueira (2008, p. 189) afirma que, na atualidade, a fotografia "dessacralizou-se; desprendeu-se de seu encanto de algo que, de forma especial e elaborada, registrava para a posteridade momentos paradigmáticos para a constituição da memória social, em sua dimensão familiar e coletiva".

Portanto, cabe à escola abrir mais espaços para a compreensão dos regimes de visualidade, dos modos atuais de representação pictórica e fotográfica, bem como tentar compreender sua trajetória, sua história, sua constituição - o que passa, necessariamente, pela história da Fotografia e de suas diversas funções. Ademais, a escola pode adotar, como tema transversal, a fotografia ou a história da Fotografia, como pode também ensinar conteúdos da história - e outras disciplinas - através da fotografia.

Para Armando Martins de Barros, o estudo da fotografia e de sua inserção na escola 
Remete-nos a dois campos importantes em nossas considerações: o papel da nova história cultural na promoção do diálogo entre as práticas do olhar - historicizando a produção, circulação e significação das imagens - e as práticas escolares produzindo novos sentidos em fotografias para ou sobre a escola; o papel desempenhado pelos cursos de Pedagogia na valorização das linguagens verbo visuais quando da formação dos pedagogos. (BARROS, 2005, p. 192).

Quando mencionamos a importância do uso das imagens - sejam fotográficas ou não nas escolas, esquecemos de nos referir aos educadores que atuam nessas escolas. No entanto, eles são os principais agentes formadores e facilitadores quanto às escolhas feitas quando optam por trabalhar determinados conteúdos e imagens em salas de aula. De acordo com Barros, na história recente,

As práticas escolares - envolvendo as instituições, os professores, os alunos, os pais, os editores, os livros, as pedagogias, os conteúdos - interagem com as "práticas do olhar", mediante o recurso a imagens em suportes como revistas pedagógicas, jornais para professores, livros didáticos, álbuns de família, cartões-postais, filmes educativos, programas em vídeo ou computador. (BARROS, 2005, p. 195).

Os educadores que se apropriam de tais imagens e realizam atividades com seus alunos em sala de aula têm a consciência do poder de significação contido nas imagens, conseguem desenvolver estratégias eficientes de comunicação e compreensão quanto ao uso destas imagens e saem à frente daqueles que utilizam as imagens somente como suporte ilustrativo dos textos verbais.

Para Kossoy (2001, p. 26), o mundo, após o advento da fotografia, tornou-se "de certa forma familiar, o homem passou a ter um conhecimento mais preciso e amplo de outras realidades que lhe eram, até aquele momento, transmitidas unicamente pela tradição escrita, verbal e pictórica”. A fotografia contribuiria decisivamente para formar o novo imaginário estético de uma época, e isto, mudaria radicalmente as relações de visualidade a partir do que as pessoas estavam acostumadas a ver em seu cotidiano.

Para Régis Debray,

Não há, de um lado, a imagem - material, única, inerte, estável - e, de outro, o olhar. Olhar não é receber, mas colocar em ordem o visível, organizar o seu sentido do 
olhar, assim como o escrito da leitura. [...] Na cidadela das imagens, uma história das utilizações e sociabilidades do olhar pode revisitar utilmente a história da arte. [...] As culturas do olhar não são independentes das revoluções técnicas que, a cada época, vêm modificar o formato, os materiais, a quantidade de imagens de que uma sociedade deve se assenhorear. (DEBRAY, 1993, p. 91).

É através do surgimento da era das imagens técnicas, há cerca de cento e setenta anos, iniciando com a fotografia e depois com o cinema, o vídeo, a televisão e, por último, o computador, os tablets e os smartphones, que a produção, a difusão, a recepção e a apropriação das imagens por parte dos sujeitos tornaram-se algo com extraordinárias dimensões. Um fenômeno que ainda estamos por compreender quando nos referimos à educação do olhar ou as práticas do olhar. O fato é que as crianças e os jovens de hoje, que fotografam e filmam as mais diversas cenas de seu cotidiano, desconhecem as etapas e os processos históricos relacionados à fotografia e as tecnologias usadas para capturar e registrar imagens, bem como, suas funções sociais.

Atualmente, os aparelhos fotográficos com suas novas tecnologias substituem rapidamente os modelos anteriores, e, à medida que o tempo transcorre, esses aparelhos se extinguem, em função de não ter mais a tecnologia capaz de fazer a leitura de um aplicativo ou programa específico. Na contemporaneidade, a fotografia - como ferramenta - está disponível praticamente a todos, banalizada por aparatos técnicos popularizados, como, por exemplo, nos celulares com câmeras (smartphones), bem como pela democratização do acesso à internet. Nesse sentido, a escola e os educadores têm, cada vez mais, um papel decisivo na ampliação das discussões quanto ao uso destas novas tecnologias, bem como, quanto as suas potencialidades.

Espera-se que, por meio do ensino da arte e do ensino da história da fotografia, a força e o potencial semântico, sociológico, antropológico, histórico e artístico desses modos de expressão, sempre em expansão, possam ser aproveitados devidamente, inclusive, fazendo uso de seu passado e de sua trajetória para melhor compreendê-los, praticá-los e adotá-los na contemporaneidade e no futuro.

\section{SOCIAL, CULTURAL AND ARTISTIC FUNCTION OF PHOTOGRAPHIC IMAGE}

\section{Abstract}


LOPES, Patricia Peruzzo.

The main objective of this paper is analyze the changes occurred in the practices of the society point of view using images from pictorial and different techniques of engraving and trying, also, to understand how after the advent of photography in the second quarter of the nineteenth century, changes occurs in the visual schemes present in this society. It is well know, with the spread of photography as art, has changed people's relationship with the images, not only in artistic and aesthetic prisms, but in social, cultural and political. This work traces a panorama of photograph trajectory and explicit its relationship to art and education, based in Boris Kossoy and Rosalind Krauss theory's, seeking to draw a historicalcultural panorama of photography, and also with François Soulages when it comes to aesthetic research on photography. This work use Cerqueira and Barros propositions to think about the relationship between photography and education.

Keywords: Photography; History; Photographic reproductions; Arts; Museum

\section{FUNCIÓN SOCIAL, CULTURAL Y ARTÍSTICO DE IMAGEN FOTOGRÁFICA}

\section{Resumen}

El objetivo de este trabajo es analizar los cambios que se produjeron en las prácticas de la mirada de una sociedad que está acostumbrada a ver las imágenes de las representaciones gráficas y las diversas técnicas del grabado. Es, además, tratar de entender cómo, después de la aparición de la fotografía, en el segundo trimestre del siglo 19, cambiaron los planes de la visualidad presente en esta sociedad. Es bien sabido que, con la difusión de la fotografía, mientras que técnica, ha cambiado la relación de las personas con las imágenes, no sólo en relación al prisma artístico y estético, pero en aspectos sociales, culturales y políticos. Muestro un panorama de la trayectoria de la fotografía y explico su relación con el arte y la educación. Para eso, converso con las teorías propuestas por Boris Kossoy y Rosalind Krauss, que buscan dibujar un panorama histórico-cultural de la fotografia, y también, con Francois Soulages con respecto a la investigación estética en la/ de la Fotografia. Me adueño de las proposiciones de Cerqueira y Barros para pensar la relación entre la fotografía y la educación. 
Palabras clave: Fotografía; Historia; Reproducciones fotográficas; Arte; Museo

\section{REFERÊNCIAS}

BARROS, Armando. Educando o olhar: notas sobre o tratamento das imagens como fundamento na formação do pedagogo. In: SAMAIN, E. (Org.). O Fotográfico. $2^{\mathrm{a}}$ ed. São Paulo: Editora Hucitec/Editora SENAC São Paulo, 2005.

BENJAMIN, Walter. Pequena história da fotografia. In: Magia e técnica, arte e política: ensaios sobre literatura e história da cultura. São Paulo: Brasiliense, 1994.

A obra de arte na era de sua reprodutibilidade técnica. In: Magia e técnica, arte e política: ensaios sobre literatura e história da cultura. São Paulo: Brasiliense, 1994.

CERQUEIRA, F. V.; PEIXOTO, L. da S.; GEHRKE, C. Fotografia e memória social: etnografia de uma experiência em um núcleo rural de colonização italiana em Pelotas. In: MICHELON, F. F.; TAVARES, F. S. (Org.). Fotografia e Memória. Pelotas: Editora Universitária da UFPEL, 2008.

DEBRAY, Régis. Vida e morte da imagem: uma história do olhar no ocidente. Petrópolis: Vozes, 1993.

FABRIS, Annateresa. Fotografia e arredores. Florianópolis: Letras Contemporâneas, 2009.

HERNÁNDEZ, Fernando. A cultura visual como um convite à deslocalização do olhar e ao reposicionamento do sujeito. In: TOURINHO, I; MARTINS R. Educação da cultura visual: conceitos e contextos. Santa Maria: Ed. da UFSM, 2011.

KOSSOY, Boris. Fotografia \& História. 2a ed. São Paulo: Ateliê Editorial, 2001.

Fotografia \& História. $3^{\text {a }}$ ed. São Paulo: Ateliê Editorial, 2009.

. Dicionário Histórico-Fotográfico Brasileiro: fotógrafos e ofício da fotografia no Brasil (1833-1910). São Paulo: Instituto Moreira Salles, 2002.

- Figura 1. Paço da cidade. Possivelmente a primeira vista pelo sistema de daguerreótipo tomada na América do Sul. Fotografia. Cf. Dicionário Histórico-Fotográfico Brasileiro: fotógrafos e ofício da fotografia no Brasil (1833-1910). São Paulo: Instituto Moreira Salles, 2002.

Figura 2. Diferentes modelos de carte-de-visite de Joaquim Feliciano Alves Carneiro e seus associados. Fotografia. Cf. Dicionário Histórico-Fotográfico Brasileiro: fotógrafos e ofício da fotografia no Brasil (1833-1910). São Paulo: Instituto Moreira Salles, 2002.

KRAUSS, Rosalind. O Fotográfico. Barcelona: Gustavo Gili, 2002. 
LOPES, Patricia Peruzzo.

NEDEL, Leticia. Patrimônio e memória: convite para um diálogo. Esboços. Revista do Programa de Pós-Graduação em História da UFSC. Florianópolis, v. 18, n. 26, semestral, dez. 2011, p. 1-13.

Disponível em: <www.periodicos.ufsc.br/index.php/esbocos> . Acesso em: 15 Jan. 2015.

PERUZZO, A. Figura 3. Retrato fotográfico em estúdio, Arthur A. Peruzzo, Elidia Vicari Peruzzo e seus filhos, cerca de 1952. Negativo Fotográfico em chapa de vidro. Coleção Particular.

Figura 4. Retrato fotográfico em estúdio, Arthur A. Peruzzo, Elidia Vicari Peruzzo e seus filhos, cerca de 1950. Fotografia em Papel. Coleção Particular.

PERUZZO, P. Figura 5. Câmera Rolleiflex, médio formato. 2012. Fotografia. Coleção Particular.

Figura 6. Peça de usina em Herval d' Oeste, SC. 2012. Negativo Fotográfico em chapa de vidro. Coleção Particular.

ROUILLÉ, André. A Fotografia: entre documento e arte contemporânea. Tradução Constancia Egrejas. São Paulo: Editora SENAC, 2009.

SOULAGES, François. Estética da Fotografia: perda e permanência. Tradução Iraci D. Poleti e Regina S. Campos. São Paulo: Editora SENAC, 2010.

Data de recebimento: $12 / 05 / 2015$

Data de aceite: $12 / 05 / 2015$ 